\title{
Hot Callusing for Propagation of American Beech by Grafting
}

David W. Carey

U.S. Forest Service, Northern Research Station, 359 Main Road, Delaware, $\mathrm{OH} 43015$

\author{
Mary E. Mason \\ Department of Entomology, Ohio Agricultural Research and Development \\ Center, The Ohio State University, 1680 Madison Avenue, Wooster, OH \\ 44691
}

\section{Paul Bloese}

Department of Forestry, Tree Research Center, Michigan State University, 3091 East Jolly Road, Lansing, MI 48910

\section{Jennifer L. Koch ${ }^{1}$}

\section{U.S. Forest Service, Northern Research Station, 359 Main Road, Delaware,} $\mathrm{OH} 43015$

Additional index words. Fagus grandifolia, Cryptococcus fagisuga, Neonectria spp.

\begin{abstract}
To increase grafting success rate, a hot callus grafting system was designed and implemented as part of a multiagency collaborative project to manage beech bark disease (BBD) through the establishment of regional BBD-resistant grafted seed orchards. Five years of data from over 2000 hot callus graft attempts were analyzed using a logistic regression model to determine which factors were important in graft success. Variables having the largest influence included scion genotype, technical problems, health issues (such as chlorosis or dwarfing), and contamination. Very few genotypes had significantly lower success compared with the average genotype, indicating that this method should be widely applicable. Comparison of the hot callus method with traditional grafting demonstrated that the odds of success using the hot callus method were 17 times greater than traditional grafting methods. Hot callus grafting is an efficient method for propagating American beech selections resistant to BBD for the establishment of seed orchards and superior clones with value as ornamentals.
\end{abstract}

American beech (Fagus grandifolia) is a common, slow-growing deciduous tree native to most of the eastern United States. American beech is monoecious and generally outcrossing (Koch et al., 2010a), but root sprouts are also a common method of regeneration in the forest and may lead to clonal clumps within stands. Mature trees on good sites can reach $50 \mathrm{~cm}$ in diameter at breast height and attain heights of over $24 \mathrm{~m}$ and generally produce good nut crops on 2- to 8 -year intervals after reaching 40 years of age (Tubbs and Houston, 1990). American beech provides food and habitat for over 40 different species of birds and mammals and is an important component of hardwood and mixed hardwood forests in eastern North America (Gysel, 1971; McCullough et al., 2001). It is a significant tree species in urban forests, identified as the species of greatest importance

Received for publication 23 Jan. 2013. Accepted for publication 20 Mar. 2013.

We thank our collaborators and partners that collected scion in the field: Paul Berrang, Carrie Sweeney, Tom Hall, Tim Frontz, Robert Heyd, Andrea Hille, Glen Juergans, and Richard Mergener. ${ }^{1}$ To whom reprint requests should be addressed; e-mail jkoch@fs.fed.us. in Washington, DC (Nowak et al., 2006) and listed as one of the most important park trees in Boston (Welch, 1994). Increased public awareness of the value of planting native species has resulted in interest in the use of American beech as a landscape tree as well, recently being named a "problem-free tree for Virginia landscapes" by the Virginia Cooperative Extension (Hansen, 2009).

Beech bark disease has had a devastating impact on American beech in both natural and urban settings and is the most important health problem of beech, significantly limiting its life and use. BBD is a slow-spreading invasive disease complex consisting of the beech scale insect, Cryptococcus fagisuga, and either Neonectria ditissima or Neonectria faginata as the fungal component. Mortality levels in the initial wave of the disease are reported as high as $50 \%$, and surviving trees are left deformed, resulting in the loss of merchantable timber, overall stand health, many wildlife and ecosystem services in forests, and reduced aesthetic value in landscape settings (Ehrlich, 1932; Houston, 1983; Morin et al., 2007). However, some trees are resistant to the insect portion of the complex, which is sufficient to prevent disease and this resistance is heritable (Koch et al., 2010b). Efficient vegetative propagation of scale-resistant American beech genotypes is required for seed orchard establishment for urban and natural forest reforestation, for cultivar development for the landscape and nursery industries, and for conserving germplasm.

Attempts at propagating American beech using vegetative techniques such as rooting of cuttings and micropropagation produced plantlets, but they failed to overwinter (Barker et al., 1997; Loo et al., 2005; Pond, 2008). Top grafting was more successful with take rates of $30 \%$ reported in the first year by Ramirez et al. (2007). However, this rate declined to $12 \%$ in the second year of their study. In 2002-04, our attempts at traditional grafting of American beech using both side veneer and top cleft graft methods yielded an overall take rate of $19 \%$. In 2002, we contracted a nursery to graft scion that we supplied, and their graft success rate was $17 \%$ in the first year with second-year survival of less than $1 \%$. For grafting to be feasible for seed orchard establishment and cultivar propagation, success rates need to be improved. Hot callus grafting (Lagerstedt, 1981), which heats the graft union while keeping the rootstock and scion cool, can significantly increase graft success of woody plants (Avanzato and Tamponi, 1987; Lagerstedt, 1984). Our objective was to use a hot callus system to improve the success rate of grafting BBD-resistant American beech trees and identify factors influencing success rates.

\section{Materials and Methods}

Propagation of rootstocks. American beech does not have standard rootstock types or varieties so each grower must collect or purchase nuts to produce seedlings for use as rootstocks. Beech nuts were hand-picked yearly in late September primarily from several large open-grown American beech trees located at the Dawes Arboretum, Newark, $\mathrm{OH}$. Occasionally other nuts from Ludington State Park in Michigan or from crosspollinations between Dawes and Ludington beech trees were available and used to produce rootstocks. The nuts were allowed to air-dry at room temperature until the burrs opened and the seed could easily be removed. Seeds were placed directly into cold, moist stratification at 4 to $8{ }^{\circ} \mathrm{C}$. The stratification medium was sphagnum moss (NoDampOff; Miller Lee, Millston, WI) wetted with $0.5 \mathrm{~g} \cdot \mathrm{L}^{-1}$ of Banrot (The Scotts Company, Marysville, $\mathrm{OH}$ ) and then hand-squeezed to remove excess water. Germination occurred after a minimum of $120 \mathrm{~d}$ in stratification with rates typically in the $75 \%$ to $90 \%$ range. Germinants were sown into small Deepots (D16; Steuwe and Sons, Inc., Tangent, OR). The growing media consisted of Metro Mix ${ }^{\circledR} 510$ (The Scotts Company) amended with $47 \mathrm{~g}$ Micromax micronutrients (The Scotts Company), 477 g Osmocote ${ }^{\circledR}$ Plus $15 \mathrm{~N}-3.9 \mathrm{P}-9.9 \mathrm{~K}$ (The Scotts Company), $700 \mathrm{~g}$ coarse perlite, and $75 \mathrm{~g}$ aluminum sulfate per $2.8 \mathrm{cu}$. $\mathrm{ft}$ bag. The seedlings were fertilized once per week with soluble $17 \mathrm{~N}-1.3 \mathrm{P}-14.1 \mathrm{~K}$ at $200 \mathrm{ppm}$ nitrogen. Seedlings were transplanted to larger 2.8-L round pots or square Treepots (TP49; 
Steuwe and Sons, Inc., Tangent, OR) in late summer and transferred to a lath house. In September, fertilizer application was reduced to once every other week and then discontinued. Seedlings were allowed to go dormant in the lath house and then were transferred in December to temperature-controlled storage and kept between 4 and $6{ }^{\circ} \mathrm{C}$. Seedlings used as rootstocks were 1 year old $(65 \%)$ or 2 years old (35\%), 45 to $80 \mathrm{~cm}$ tall, and had a stem diameter of 0.15 to $2.0 \mathrm{~cm}$ at the grafting site.

Scion collection. Between December and March of each year, scion was collected from mature trees as part of a region-wide program to establish BBD-resistant American beech seed orchards (Koch et al., 2012). Federal and state forest health and management personnel collected scions from selected trees (both healthy with no sign of scale or fungus and diseased controls) in state and/or national forests in Michigan, Pennsylvania, and West Virginia that are heavily impacted by BBD. Branch sections, 1 to $2 \mathrm{~m}$ long, were harvested by rifle, shotgun, pole pruner, or rope saw, placed in plastic bags, and kept in a temperature-controlled greenhouse or cold room at 4 to $6{ }^{\circ} \mathrm{C}$. In cases in which the scion had to be stored longer than 2 weeks, the proximal ends of the branches were given a fresh cut and placed in water that was replaced every 2 to $3 \mathrm{~d}$ to prevent contamination. Scions $\approx 35 \mathrm{~cm}$ in length with an average diameter of $0.48 \mathrm{~cm}$ (range, 0.1 to $2.2 \mathrm{~cm}$ ) were cut from these larger branches and immediately grafted.

Grafting. To reduce contamination, all grafting knives, tools, and the bark of scions and rootstocks were cleaned with $80 \%$ ethanol before any cuts were made. Rootstocks were carefully selected so that the scion and rootstock diameters matched at the graft union. Cleft graft cuts were made using the Fieldcraft Topgrafter (Raggett Industries Ltd., Gisborne, New Zealand), and side veneer grafts were performed following accepted practices (Garner, 2000). All grafts were secured using commonly available grafting rubbers $(0.48 \times 15.24 \mathrm{~cm}$ or $0.95 \times 20.32 \mathrm{~cm})$. For veneer grafts, two smaller diameter scions of the same genotype were grafted onto a larger rootstock but staggered onto opposite sides of the rootstock and secured separately. All grafts were coated with paraffin (to prevent the scion wood and graft union from drying out) by dipping in a $55{ }^{\circ} \mathrm{C}$ paraffin wax bath from the tip to just past the graft union (Nick Loving, personal communication). The wax bath was made by adding $30 \mathrm{~g}$ of paraffin to $7.5 \mathrm{~L}$ of reverse osmosis purified water in a clean $9.5-\mathrm{L}$ plastic bucket kept covered in a $55{ }^{\circ} \mathrm{C}$ water bath, and a fresh batch of melted paraffin was made every week. Grafts were then either kept in the cool $\left(2\right.$ to $\left.7^{\circ} \mathrm{C}\right)$ greenhouse (traditional method) or placed in the hot callus chamber.

Hot callus grafting apparatus. The hot callus grafting apparatus was based on the concept of Lagerstedt (1981). Non-automatic Redi-Heat heat cables $18.3 \mathrm{~m}$ in length were used as a heat source controlled by a RediHeat RHT4 thermostat (Phytotechnologies Inc., Earth City, MO). Four cables connected to a 20 -amp circuit were controlled by a single thermostat. Each heat cable was mounted to $10.2 \times 10.2-\mathrm{cm}$ pressure-treated posts using wire hangers (Fig. 1). Two runs of cable were placed $5.3 \mathrm{~cm}$ apart in the center of the side of a wooden post. The posts were laid horizontally across two $35.6-\mathrm{cm}$ tall support structures, one at either end. Grafts were placed in a row such that each graft union was $\approx 2 \mathrm{~cm}$ away from the two heat cables and centered between them. To achieve proper positioning of the graft between the heat cables, spacers were placed under individual pots when needed. The heat chamber was created by cutting two $5-\mathrm{cm}$ long perpendicular slits (one at the top and one at the bottom) in 19-cm wide sill plate foam at the position where a graft was placed along the cable assembly. The slits allowed the foam to be placed over the graft union and wrapped around the stem above and below the graft union, insulating the union inside the sill foam. The foam was then attached to the top and bottom of the posts with masking tape. Gaps in the foam and the ends of the foam were taped closed so that a completely sealed, thermostatcontrolled chamber was created. The heat chamber of the hot callus apparatus was kept at $24.4{ }^{\circ} \mathrm{C}$, whereas the entire apparatus was set up in either a temperature-controlled greenhouse or a cold room kept at 4 to $6{ }^{\circ} \mathrm{C}$.

Data collection. To determine variables that have a significant impact on the outcome of hot callus grafts, data collected over 6 years (2005-10) were analyzed. Graft outcome was scored as 0 for failed grafts and 1 for successful grafts. Rootstock caliper was measured $2.5 \mathrm{~cm}$ below the graft union and scion caliper was measured $2.5 \mathrm{~cm}$ above the graft union. Different aspects such as scion genotype, rootstock family, and graft date were recorded, and comments on graft and tree health were noted. All data were collected 4 to 6 weeks after first

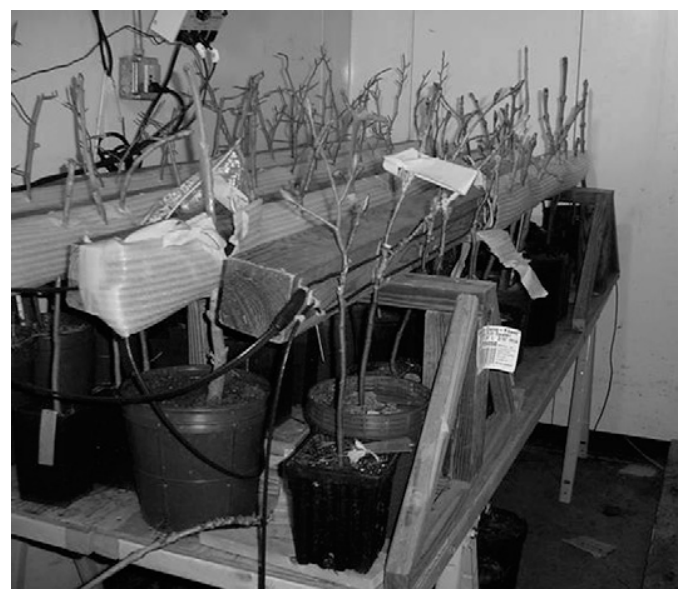

Fig. 1. Hot callus graft system set up in cold room. At the right is an open hot callus chamber showing the arrangement of pots to place the graft union (area covered in grafting rubbers) in between the heat cables (black cords attached to wood beam). To the left are three closed hot callus chambers showing the sill foam taped to the end of the wood beam and taped closed around the protruding rootstocks and scions (the end graft on the second from the right beam is not yet taped closed). The electrical controller for the heat cables is visible mounted on the back wall of the cold room. The temperature probe cables are not visible but also connect to the controller to maintain proper temperature inside the hot callus chambers. Also visible is the paraffin coating on the grafts and scions to prevent drying out before the graft healing. budbreak. Graft unions were visually assessed for signs of infection (bacteria, yeast, or fungi) and recorded as contaminated or uncontaminated. Health problems were also noted and included yellow or dwarfed leaves, a physically damaged graft or top (broken branch), wilt resulting from irrigation failure, or loss of vigor or failure to thrive. A callus score from 1 to 4 was assigned with 1 representing minimal formation and 4 assigned to the highes levels of callusing observed. The number of terminal scars on the grafted scion was recorded the age of the wood at the grafting site impacted graft success. Graft date and comments were coded into $0 / 1$ categorical variables. Grafts were completed between December and May and scored between April and July (depending on graft date but after all the grafts in the set had either flushed or failed).

Statistical analysis. Logistic regression sis was used with graft outcome as the dependent variable and 13 independent variables as listed in Table 1. These variables were explanatory variables in a logistic regression of graft outcome (Agresti, 1996; Neter al., 1996). Logistic regression is a slight that is valid for non-normal response variables (such as whether a graft is alive or dead or the proportion of grafts that is successful). It is useful in the same situations ordinary linear between in useful: to explore the relationship variable) and potential explanatory variables (i.e., the $\mathrm{X}$ variables). Some minor data editing was done to facilitate modeling (some levels of original data categories were merged and five families were causing model fitting problems so one graft per family was chosen at random and changed to allow model convergence and therefore retain those families). 
Table 1. The variables measured on grafts and used as potential explanatory variables in the data model including whether explanatory variables were quantitative (measured on a continuous scale), class (with several distinct levels), or indicator variables ( 1 represents the condition/event is true/present and 0 is absent/ false).

\begin{tabular}{|c|c|c|}
\hline Variable name & Type & Description \\
\hline Outcome & Binary response & $1=$ graft was successful, $0=$ graft unsuccessful \\
\hline Year & Class explanatory & Year of the graft \\
\hline Scion genotype & Class explanatory & Genotype of the scion used for the graft ( 74 total) \\
\hline Graft type & Class explanatory & Top cleft or side veneer \\
\hline Rootstock family & Class explanatory & Family of the rootstock used ( 3 primary and 8 supplemental) \\
\hline Terminal scars & Class explanatory & Number of terminal scars on the scion as grafted (number of years of growth at graft point) \\
\hline Callus score & Class explanatory & Amount of callus, increasing from 1 to 4 \\
\hline Health problem & Indicator explanatory & $1=$ had a health problem post-graft (chlorosis, dwarfing, wilting, etc.), $0=$ no problem \\
\hline Graft/technical problem & Indicator explanatory & $\begin{array}{l}1 \text { = had a grafting or technical problem (bands too tight, physically broken, misaligned top } \\
\text { cleft graft, heating problem with hot callus system, etc.), } 0=\text { no problem }\end{array}$ \\
\hline Contamination & Indicator explanatory & $1=$ fungal, yeast, or bacterial contamination in or around graft union, $0=$ no contamination \\
\hline Rootstock caliper & Quantitative explanatory & Caliper measured $2.5 \mathrm{~cm}$ below graft union (range is $0.15 \mathrm{~cm}$ to $2.0 \mathrm{~cm}$ ) \\
\hline Scion caliper & Quantitative explanatory & Caliper measured $2.5 \mathrm{~cm}$ above graft union(range is $0.05 \mathrm{~cm}$ to $1.6 \mathrm{~cm}$ ) \\
\hline
\end{tabular}

A forward selection regression model was fit for the binary response variable outcome, entering all the variables as main effects, and using the forward selection option at $\alpha=0.05$ as the rule to add a variable to the model (using SAS Enterprise Guide Version 4.2; SAS Institute Inc., Cary, NC). Model fit was verified by goodness-of-fit tests, examining residuals and leverages for the model, calculating maximum rescaled $R^{2}$, and concordance of predicted probabilities with outcomes. To explore the significant variables in more detail, we computed parameter estimates and odds ratios. Significance of the parameter estimates was verified using the Wald $\chi^{2}$ test. For odds ratios, we computed the point estimate and the $95 \%$ Wald confidence interval. In this case, odds ratio is the ratio of the odds of success for one level over the odds of success for the comparison level. Examination of odds ratios allows exploration of the direction and magnitude of significant effects on graft success.

Hot callus versus traditional grafting. Using 2010 data, the hot callus system was directly compared with traditional grafting. Both treatments used the same rootstock and the same subset of seven scion genotypes. A logistic regression of the success rate (success/attempts) of the grafts was performed with explanatory variables genotype and treatment (hot callusing or traditional graft) entered as main effects. For this model, we used PROC LOGISTIC (SAS 9.2) to fit the model and calculate parameter estimates and odds ratios.

\section{Results}

Factors influencing hot callus grafting. In 2005 , we initiated a program using a hot callus graft apparatus (Fig. 1) and our overall take rate for the year increased to $57 \%$. Data from grafts performed in 2005-10 were analyzed using a logistic regression model to identify the variables (Tables 1 and 2) that most influenced graft success in an attempt to further improve on the technique. Eight of the 11 potential explanatory variables had significant effects (Table 2), whereas three were not significant (year, terminal scars, and rootstock caliper). To assess the direction and relative magnitude of the effect of the significant variables in the model, parameter estimates and odd ratios were calculated (Table 3).

Genotype 4419304 was chosen as the base for calculating odds ratios because its parameter estimate was closest to zero, so it represents an "average" performing tree. Relative to genotype 44419304, only six genotypes (out of 74 included in the study) were particularly poor performers (odds ratio less than 1) and four were particularly good performers (odds ratio greater than 1; Table 3). This indicates that grafting with hot callusing should be widely applicable across a variety of American beech scion genotypes. There are no standard rootstocks for use in beech grafting so we looked carefully at rootstock family effects. Only one rootstock family out of the 11 was significantly different and it performed more poorly than the others. The three rootstock families that were used most frequently had average performance indicating that a generally good rootstock family may be easily identified for use in grafting. Scion caliper, graft type, and callus score all had significant differences. Scion caliper is significant and has a positive effect, indicating that increasing scion caliper results in improved graft success. Side veneer grafts were 3.9 times more likely to be successful than top cleft grafts. Additionally, side veneer graft success increased linearly with increasing scion caliper (data not shown). However, top cleft grafts were still highly successful over the 5 years of data collection and may be preferred for certain uses of the trees such as grafting larger mature scion material that has preformed flower buds so that containerized controlled cross-pollinations can be performed (Koch et al., 2007). Callus score, a measure of the extent of callusing at the graft union, was also significant. Not unexpectedly, the more callusing that occurred, the better the odds of success. Grafts with the highest callus score of 4 (highest amount of callus) were 23.8 times more likely to be successful relative to grafts that had the lowest callus score of 1 (very little callus formation). Technical grafting problems, contamination issues, and health problems all had a large impact on graft outcome with odds of success improving by $2.9,4.1$, and 17.7 times, respectively, for grafts lacking these problems.
Table 2. Significant effects, the order they entered the forward selection model, and the Wald test for each variable included in the logistic regression model of the American beech graft success.

\begin{tabular}{lcrrr}
\hline & $\begin{array}{c}\text { Model } \\
\text { order }\end{array}$ & df & Wald $\chi^{2}$ & $P$ value \\
Effect $^{z}$ & 1 & 3 & 194.0658 & $<0.0001$ \\
\hline Callus score & 2 & 1 & 59.4820 & $<0.0001$ \\
Contamination & 3 & 1 & 114.2634 & $<0.0001$ \\
Scion caliper & 4 & 73 & 182.4860 & $<0.0001$ \\
Genotype & 5 & 1 & 49.0332 & $<0.0001$ \\
Graft type & 6 & 1 & 10.1708 & $<0.0001$ \\
Graft/technical & & & & \\
$\quad$ problem & 7 & 10 & 35.9871 & $<0.0001$ \\
Rootstock family & 8 & 1 & 6.2651 & 0.0123 \\
Health problem & 8 &
\end{tabular}

${ }^{\mathrm{z}}$ The model was well fit (likelihood ratio, score, and Wald tests for global goodness of fit all $P<0.001$ ) and graphical analysis of residuals detected no major influential points or leverages. The model explained a large part but not all of the variation in graft success (maximum rescaled $R^{2}=0.6331$ and $92 \%$ concordance between model prediction and observed values). The variables year, terminal scars, and rootstock caliper did not meet the forward selection criteria and were not added to the model.

Direct comparison of traditional versus hot callus grafting methods. Our take rate improved from $19 \%$ using traditional grafting methods to $57 \%$ the first year hot callus grafting was performed and was $52 \%$ for 2005-08 combined. To confirm this was the result of the hot callus system, we directly compared traditional and hot callus grafting methods in 2010 using a subset of the scion genotypes. Logistic regression analysis indicated that grafting system (hot callusing vs. traditional grafting) was significantly different $(P<0.0001)$ but that genotype was not $(P=0.4875)$. The hot callus system had 17.54 ( $95 \%$ confidence interval, 7.5 to 40 ) times the odds of success than the traditional grafting set-up with a $67 \%$ success rate across all eight genotypes compared with $13 \%$ success rate for the traditional grafting set-up. Success rates for the different genotypes between hot callus grafting and traditional grafting are shown in Figure 2.

\section{Discussion}

Of the 74 different genotypes grafted, only 10 were significantly different from the 
Table 3. Maximum likelihood parameter estimate (MLE) and odds ratio information for levels of variables that are significantly different from zero at the $\alpha<0.05$ level for the forward selection model.

\begin{tabular}{|c|c|c|c|c|c|c|c|c|c|}
\hline Parameter $(\beta)$ & Level & df & $\begin{array}{l}\text { MLE estimate } \\
\text { of beta }\end{array}$ & $\begin{array}{l}\text { MLE SE of } \\
\text { beta }\end{array}$ & $\frac{\text { MLE Wald }}{\chi^{2} \text { of beta }}$ & $\frac{\text { MLE }}{\operatorname{Pr}>\chi^{2} \text { of beta }}$ & $\begin{array}{c}\text { Odds ratio } \\
\text { comparison level }^{\mathrm{y}}\end{array}$ & $\begin{array}{c}\text { Odds ratio point } \\
\text { estimate }^{z}\end{array}$ & $\begin{array}{c}\text { Odds ratio } 95 \% \text { Wald } \\
\text { confidence interval }\end{array}$ \\
\hline Scion caliper & $\mathrm{N} / \mathrm{A}$ & 1 & 5.818 & 0.544 & 114.263 & $<0.0001$ & $\mathrm{~N} / \mathrm{A}$ & $\mathrm{N} / \mathrm{A}$ & N/A \\
\hline Genotype & 1520 & 1 & -3.738 & 1.114 & 11.258 & 0.0008 & 4491304 & 0.067 & $(0.007,0.674)$ \\
\hline Genotype & 4693615 & 1 & -3.232 & 0.717 & 20.312 & $<0.0001$ & 4491304 & 0.110 & $(0.023,0.537)$ \\
\hline Genotype & 4694207 & 1 & -2.750 & 1.022 & 7.241 & 0.0071 & 4491304 & 0.179 & $(0.021,1.508)$ \\
\hline Genotype & BEWL-01 & 1 & 2.545 & 0.751 & 11.483 & 0.0007 & 4491304 & 35.680 & $(6.837,186.203)$ \\
\hline Genotype & MI-1214 & 1 & -1.630 & 0.508 & 10.309 & 0.0013 & 491304 & 3.940 & $(0.946,16.415)$ \\
\hline Genotype & MI-1215 & 1 & -3.332 & 1.198 & 7.735 & 0.0054 & 4491304 & 0.549 & $(0.158,1.909)$ \\
\hline Genotype & MI-1220 & 1 & -2.170 & 0.575 & 14.224 & 0.0002 & 4491304 & 0.320 & $(0.083,1.224)$ \\
\hline Genotype & MI-1221 & 1 & -2.140 & 0.574 & 13.888 & 0.0002 & 4491304 & 0.330 & $(0.086,1.258)$ \\
\hline Genotype & MI-1229 & 1 & 1.812 & 0.673 & 7.253 & 0.0071 & 4491304 & 17.144 & $(3.767,78.027)$ \\
\hline Genotype & MI-1231 & 1 & 2.394 & 0.900 & 7.076 & 0.0078 & 4491304 & 30.685 & $(4.454,211.391)$ \\
\hline Graft type & Side veneer & 1 & 0.689 & 0.098 & 49.033 & $<0.0001$ & Top cleft & 3.970 & $(2.696,5.839)$ \\
\hline Rootstock family & DN00726 $\times 1506$ & 1 & -1.391 & 0.403 & 11.938 & 0.0006 & Unknown & 0.043 & $(0.003,0.619)$ \\
\hline Callus score & 1 & 1 & -2.033 & 0.147 & 192.355 & $<0.0001$ & 4 to $1^{\mathrm{x}}$ & $23.81^{y}$ & $(13.82,45.46)^{\mathrm{y}}$ \\
\hline Callus score & 3 & 1 & 0.692 & 0.171 & 16.302 & $<0.0001$ & 4 to $3^{x}$ & $2.58^{y}$ & $(1.38,4.8)^{\mathrm{y}}$ \\
\hline $\begin{array}{l}\text { Graft/technical } \\
\text { problem }\end{array}$ & 0 & 1 & 0.711 & 0.162 & 19.171 & $<0.0001$ & Has a problem & 4.144 & $(2.193,7.831)$ \\
\hline Contamination & 0 & 1 & 1.437 & 0.186 & 59.482 & $<0.0001$ & Has the problem & 17.669 & $(8.523,36.709)$ \\
\hline Health problem & 0 & 1 & 0.531 & 0.212 & 6.265 & 0.0123 & Has the problem & 2.890 & $(1.259,6.632)$ \\
\hline
\end{tabular}

${ }^{\mathrm{z}}$ Odds ratios $<1.0$ mean the variable is worse than the comparison level for the parameter.

${ }^{y}$ Comparison level is the denominator of the odds ratio and is the level of the variable we chose as the base level.

${ }^{\mathrm{x}}$ To compare callus score of 4 to the lower level scores, the odds ratio point estimate was inverted as well as the Wald confidence interval. $\mathrm{N} / \mathrm{A}=$ not applicable.

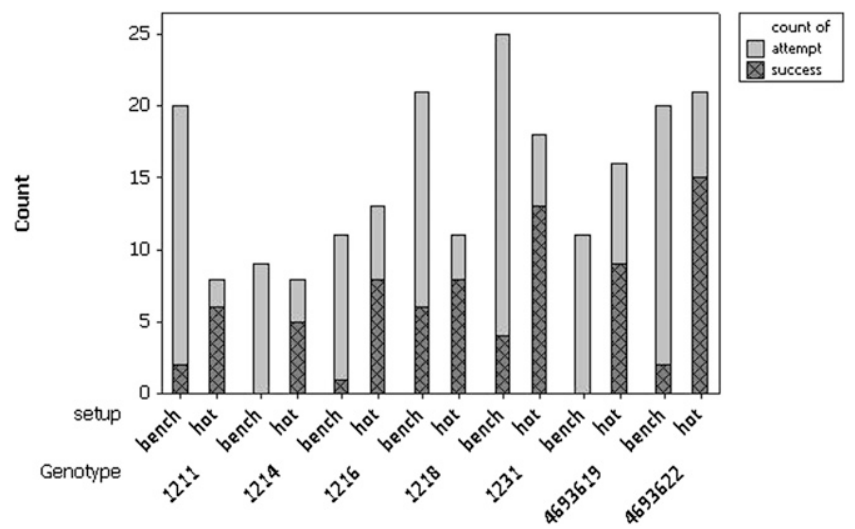

Fig. 2. Comparison of overall success rates of traditional (bench) and hot callus grafting methods for eight genotypes of BBD-resistant American beech. A logistic regression showed that hot callusing was significantly better than the traditional method, but there were no significant differences among the genotypes (genotype $P=0.4875$, setup $P<0.0001$ ). BBD $=$ beech bark disease.

average genotype. Of these 10 , six performed more poorly, whereas four performed better. This indicates that although there is a significant genotype effect, most trees perform typically and only a few are very good or very bad. Therefore, a diverse selection of trees may be propagated through grafting and it is likely that trees with desirable horticultural traits in addition to BBD resistance may be successfully propagated using this technique. Grafted seed orchards should be able to capture significant levels of diversity along with the BBD resistance trait to provide a good source of beechnuts for restoration plantings. Although graft type was significant and veneer grafts more successful than top cleft grafts, the magnitude of the difference was small and either graft type could be used. The graft type can be chosen based on the desired product such as in the case of containerized seed orchards, larger top cleft grafts are used with scions having multiple pre-formed flower buds to maximize nut production (Koch et al., 2007). The significant effect of technical problems, health problems, and contamination indicates that there is room for improvement on our methods. Success rates should improve once corrective measures are implemented such as the addition of sterilization steps to reduce contamination and additional training of grafters to avoid technical problems.

Direct comparison between American beech graft attempts using the hot callus apparatus and those performed following traditional methods demonstrated a clear increase in success rate (67\% vs. $13 \%)$ across eight different genotypes that justify the additional expense of using the hot callus apparatus (Fig. 2). The success rate $(67 \%)$ surpasses our previous traditional rate of $19 \%$ as well as the yearly take rates of $30 \%$ and $12 \%$ reported by Ramirez et al. (2007). In addition, hot callus grafting was performed without significant differences in success rates over a period of months (December through March) vs. a very limited window of time that traditional grafting is normally performed in $(\approx 2$ weeks in late winter/early spring). This extended timeframe increases the number of grafts that can be produced in 1 year.

In conclusion, the use of hot callus grafting to propagate American beech is more effective than traditional approaches and can be used across diverse genotypes. This method of propagation can be used by the nursery and landscape industries to develop and distribute cultivars and is currently part of forest health management activities to develop BBDresistant American beech seed orchards. The success rates will likely improve as methods are refined and techniques implemented to reduce health, technical, and contamination problems.

\section{Literature Cited}

Agresti, A. 1996. An introduction to categorical data analysis. John Wiley and Sons, Inc., New York, NY.

Avanzato, D. and G. Tamponi. 1987. The effect of heating walnut graft unions on grafting success. Acta Hort. 227:79-83.

Barker, M.J., P.M. Pijut, M.E. Ostry, and D.R. Houston. 1997. Micropropagation of juvenile and mature American beech. Plant Cell Tiss. Org. Cult. 52:209-213.

Ehrlich, J. 1932. The beech bark disease. A nectria disease of Fagus, following Cryptococcos fagi (Baer.). Can. J. For. Res. 10:593-692.

Garner, R.J. 2000. The grafter's handbook. Oxford Univ. Press, New York, NY.

Gysel, L.W. 1971. A 10-year analysis of beechnut production and use in Michigan. J. Wildl. Mgt. 35:516-519.

Hansen, M.A. 2009. Problem-free trees for Virginia landscapes. VA Coop Ext. Pub. 450-237. Virginia Polytech. Inst. and State Univ., Blacksburg, VA.

Houston, D.R. 1983. American beech resistance to Cryptococcus fagisuga. In: Proc. IUFRO beech 
bark disease work party conf. USDA For. Serv. Gen. Tech. Rep. WO-37. p. 38-42.

Koch, J.L., D.W. Carey, and M.E. Mason. 2010a. Use of microsatellite markers in American beech (Fagus grandifolia) population and paternity testing. Silvae Genet. 59:2-3.

Koch, J.L., D.W. Carey, M.E. Mason, and C.D. Nelson. 2010b. Assessment of beech scale resistance in full- and half-sibling American beech families. Can. J. For. Res. 40:265-272.

Koch, J.L., M.E. Mason, and D.W. Carey. 2007. Advances in breeding American beech for resistance to beech bark disease, p. 22-28. In: David, A. (ed.). Proc. $3^{\text {rd }}$ Northern Forest Genet. Assoc. Wkshp. Univ. of MN Dept. For. Res. Staff Pap. Ser. No. 194.

Koch, J.L., M.E. Mason, and D.W. Carey. 2012. Screening for resistance to beech bark disease: Improvements and results from seedlings and grafted field selections, p. 196-208. In: Palmieri, K. and R. Sneizko (eds.). Proc. of the 4th International Workshop on Genetics of HostParasite Interactions in Forestry. Gen. Tech. Rep. PSW-GTR-240.
Lagerstedt, N.B. 1981. A new device for hotcallusing graft unions. HortScience 16:529-530.

Lagerstedt, N.B. 1984. Hot callusing pipe speeds up grafting. Amer. Nurseryman October: 113-117.

Loo, J.A., M. Ramirez, and M. Krasowski. 2005. American beech vegetative propagation and genetic diversity, p. 106-112. In: Evans, C.A., J.A. Lucas, and M.J. Twery (eds.). Beech bark disease: Proc. of the beech bark disease symposium. U.S. Depart. of Agr., Forest Serv., Northern Research Sta., Newtown Square, PA. Gen. Tech. Rep. NE-331.

McCullough, D.G., R.L. Heyd, and J.G. O'Brien. 2001. Biology and management of beech bark disease: Michigan's newest exotic forest pest. Michigan State University Bulletin E-2746.

Morin, R.S., A.M. Liebhold, P.C. Tobin, K.W. Gottschalk, and E. Luzader. 2007. Spread of beech bark disease in the eastern United States and its relationship to regional forest composition. Can. J. For. Res. 37:726-736.

Neter, J., M.H. Kutner, C.J. Nachtsheim, and W. Wasserman. 1996. Applied linear regression models. 3rd Ed. Irwin, Chicago, IL.
Nowak, D.J., R.E. Hoehn III, D.E. Crane, J.C. Stevens, and J.T. Walton. 2006. Assessing urban forest effects and values, Washington, DC's urban forest. U.S. Depart. of Agr., Forest Serv., Northern Research Sta., Newtown Square, PA. Resour. Bull. NRS-1.

Pond, S. 2008. Conservation and propagation of American beech (Fagus grandifolia Ehrh.) through somatic embryogenesis. Propag. Ornamen. Plants. 8:81-86.

Ramirez, M., J. Loo, and M.J. Krasowski. 2007. Evaluation of resistance to the beech scale insect (Cryptococcus fagisuga) and propagation of American beech (Fagus grandifolia) by grafting. Silvae Genet. 56:163-169.

Tubbs, C.H. and D.R. Houston. 1990. Fagus grandifolia Ehrh., American beech, p. 325332. In: Burns, R.M. and B.H. Honkala (tech. coords.). Silvics of North America. Vol. 2, Hardwoods. Agr. Handbook, 654. USDA Forest Service, Washington, DC.

Welch, J.M. 1994. Street and park trees of Boston: A comparison of urban forest structure. Landsc. Urban Plan. 29:131-143. 